\title{
ETHNOGRAPHIC REFLECTIONS OF RETURN MIGRATION IN A ROMANIAN RURAL COMMUNITY
}

\author{
Florentina SCÂRNECI DOMNIŞORU', Codrina CSESZNEK"
}

COBISS 1.01

\begin{abstract}
Ethnographic Reflections of Return Migration in a Romanian Rural Community

The objective of the research is to describe the return migration process in a Romanian rural community; we will focus here on the identity changes experienced by community members who recently returned from Italy. We conducted this instrumental case study in Drăguş, Brasov County, where we performed extensive observations. We identified all the persons who have permanently returned from Italy and studied the perceived identity effects of their migration experience. We also collected data through narrative interviews; the data was analyzed by means of coding techniques, and the results are ethnographic reflections of return migration focusing mostly on the way the identity of our participants was shaped by the experience of migration and returning to the original community.

KEY WORDS: return migration, identity crisis, identity conversions, ethnography, qualitative data
\end{abstract}

\section{IZVLEČEK}

Etnografski odsevi povratne migracije v ruralni romunski skupnosti

V članku avtorici opisujeta proces povratne migracije v romunski ruralni skupnosti Drăguş. Posvečata se predvsem identitetnim spremembam tistih članov skupnosti, ki so se za stalno vrnili iz Italije in so posledica migracijske izkušnje. S člankom sta želeli poudariti, da so povratne migracije kljub ekonomskim, socialnim in kulturnim učinkom za skupnost v strokovni literaturi najbolj zanemarjen del migracijskega procesa, dokazati vrednost in pomen kvalitativnih podatkov in poudariti pomen ukvarjanja tako z individualnimi kot s skupinskimi spremembami identitet.

KLJUČNE BESEDE: povratna migracija, kriza identitete, etnografija, kvalitativni podatki

$\mathrm{PhD}$, Associate Professor; Faculty of Sociology and Communication, Transilvania University of Brasov, Romania, B-dul Eroilor, no. 25, fl. II, hall TII9; fscarneci@unitbv.ro

\| PhD, Associate Professor; Faculty of Sociology and Communication, Transilvania University of Brasov, Romania, B-dul Eroilor, no. 25, fl. II, hall TII9; csandru@unitbv.ro 


\section{INTRODUCTION}

We have chosen to study migration because, as Benmayor and Skotnes (2005: 4) said, "It is a basic feature of social life throughout the world today". Many migration studies have been conducted with Europeans as the subjects, i.e. Italians, Irish, Poles, Turks, etc. However, the Romanian migration specific to the post-communist era is a complex phenomenon (Sandu 2010) and it needs further exploration. In just two decades, Romania turned itself from a closed-border country into a great "exporter" on the European labor markets, particularly Italy and Spain (and more recently, France, Germany and the United Kingdom). It is estimated that in the last two decades, 2.5 million Romanians have left their country to find work abroad, thus entering the category of economic migrants people who temporarily leave their country hoping to raise financial capital (Toanchină 2006; Sandu 2006 in Horvath 2009).

The complexity of the Romanian migration phenomenon is demonstrated by its multiple social dimensions that have been analyzed in recent studies: circular migration as a life strategy (Sandu 2010), the role of remittances sent by the Romanian emigrants in the reduction of the country's payment balance (Dăianu et al. 2001), the social protection of migrants (Toanchină 2006), migrants' quality of life (Bălţătescu 2007), ethnic migration from Romania (Michalon 2009; Brubaker 2009), migration as a cultural pattern with a focus on the change of the cultural values and perceptions as determined by previous migration experiences in communities with a long migration history (Horvath 2009), the effects of migration on the development of original communities (Anghel 2009), the description of the "social worlds" of the Romanian diaspora abroad (Sandu 2010), gender differences in return migration (Vlase 2011) and so on. Nevertheless, none of these studies focused on the identity changes experienced by the emigrants, even though in our opinion these changes are generators of economic, social and cultural problems.

The migration experience correlates with identity because "migration is a life-long process of negotiating identity, difference, and the right to fully exist and flourish in the new context" (Benmayor, Skotnes 2005: 8). This is why we believe that Romanian studies on migration must focus on identity issues as well. Migration and identity-related studies can be found in the Far East, such as in Taiwan, Hong Kong, Indonesia etc. However, recently, in European migration-active societies like Italy, Spain or France (as host countries) and Eastern European countries (as departure zones), both of the related phenomena have been studied more frequently. Sandu (2010) examines the sense of identity of Romanians who work in Spain and shows that those who want to return home have a strong attachment to their local community. Cingolani (2010) analyzed how family and church are involved in the promotion and reproduction of national identity in the case of Romanians living in Italy. Kunuroglu et al. (2015) studied the consequences of Turkish return migration from Germany and emphasized the process of the reconstruction of the "migrant" identity into a "German-like" one. The intercultural experiences in the migration processes are discussed in several studies with reference to Sussman's cultural identity model, in order to discuss possible adaptation strategies and various identity shifts (Sussman 2010; Chaban et al. 2011; Kunuroglu et al. 2015).

A new trend has been taking shape in Romania in recent years: some of the migrants have been returning home with the intention to stay. This phenomenon is called "return migration" or "remigration", and was first studied as a life project. Sandu (2010) showed 
that in 2008, nearly half of the Romanian migrants in the Madrid area of Spain claimed to have plans of returning to their country in the next five years. And though there are no studies to measure the amplitude of such a phenomenon at the national level, in some Romanian communities there is enough empirical proof to support the existence of this new emigrational dimension (Vlase 2011).

Globally, return migration is a well-known phenomenon, and its dimensions and effects are the subject of concern for many specialists.

The United Nations has estimated that annually as many as 100 million people return to their homelands. [...] Seasonal workers, temporary emigrants, sojourner repatriates, and return migrants are all part of a diverse but growing global phenomenon in which individuals returning to their families, workplaces and home societies must make psychological and social adjustments. (Sussman 2010: 6)

Jones (2011) claims that return migration is one of the most overlooked aspects of international migration in the specialty literature, and that in a traditional fashion it has been the object of various quantitative economic and demographic studies. Return migration is defined as the process of people returning to their country of origin after spending a significant amount of time in another country or region (King in Thieme 2012). An emigrant's return home may seem a rather simple process given their familiarity with the cultural patterns. But recent studies show that the reintegration process in one's original country has its own difficulties (Vlase 2011). An emigrant that returns after ten or twenty years of living abroad is not the same person that left (Vlase 2011). Therefore, they experience numerous and complicated re-adaptation problems. Sociologists all over the world study migration and/or remigration processes, and we believe that one of the most important subjects of study generated by those processes is linked to identity: "The experience and effects of migration are long-term and critical in shaping and reshaping both collective and individual identities" (Benmayor, Skotnes 2005: 8).

In a study regarding the transnational experience of young Taiwanese return migrants from Australia, the authors concluded that "[t]he factors affecting the self-identity of return migrants are: age of migration, family values, peer group identity, early experience of discrimination in Australia, and intensity of relations with Taiwan" (Chiang, Liao 2008: 126-127). After studying return migration in Hong Kong, Sussman (2010) notes that "[f] requently emigrants returned home wealthier than they left, which allowed them to build bigger houses, acquire land, and create new businesses offering new products and services" (p 60). In a study regarding the status of migrants in Italy, an Italian author points out that "[i]n their new country, migrants represent the workforce necessary to guarantee and validate a comfortable life-style for a majority. In exchange, they are 'tolerated' as long as the migrants' problems remain marginal and can be publicly ignored. In the country left behind, migrants represent an economic resource on which the survival of the family is often based" (Parati 2005: 41).

The work of Adelmalek Sayad (2004) on emigration-immigration processes between Algeria and France represents a great contribution to understanding contemporary migration issues, taking into account "the suffering of the immigrants" and proposing the concept of "double absence". The "double absence" of emigrants/immigrants refers to: 1) their absence in the country of origin, which itself creates a negative image of its citizens abroad, 
treating them as simply absent or even traitors and 2) their symbolic absence in the host country, where they quickly become victims of social exclusion. Double absence represents a serious identity problem and often gives rise to mental health problems (Adamson 2007), especially for the children of immigrants who feel divided between their country of origin and their host country (Noiriel 2006). Methodologically, using semi-structured interviews, Sayad tried to understand the world of emigrants/immigrants and restored the complexity of their discourse, connecting "the two ends of the experience: the point of departure and the destination" (Noiriel 2006: 107). We have chosen to make a qualitative study of a Romanian rural community with an extensive history of emigration. It is an ethnographic study which focuses particularly on the process of identity transformation that we discovered; we have tried to flesh out the existing demographic and quantitative dimensions of the emigration phenomenon with testimonials and life aspects of people's experiences.

\section{DATA COLLECTION AND ANALYSIS}

We chose the Commune of Drăguş in Braşov County for this study for two reasons. Firstly, it is a community with an extensive migration history. During the time period from 1901-1929, almost one fifth of the village population (218 men and 52 women) emigrated to North America. During the years of the socialist regime, emigration decreased considerably due to political constraints. After 1989, there was a significant increase in migration among the people of Drăguş. Due to extremely high unemployment, the youth of Drăguş started leaving for work in the countries of Western Europe (mainly in Italy and Spain). According to statistical data available at Drăguş City Hall, in 2010 the commune's population was 1.260, of whom 167 were working abroad. In 2011, five families returned from Italy and three from Spain.

We selected the five families that returned home from Italy as participants in our research. With regard to emigrational aspects, this community is very much like other communities in Romania. This is why understanding return migration and its effects on identity matters is relevant for understanding the phenomenon in other similar communities in Romania and in other Eastern European countries. If one considers Anna's migration experience from Hong Kong to Australia and back again (see Sussman 2010) and compares this with our subjects' return migration experiences, the deep similarities are astounding. Thus, we believe that our case study could be used as means for understanding remigration identity dynamics in general (see the "instrumental case study" in Stake 1998). Of course we also have to consider the differences between cases, and this is why we think of our findings as reflections on return migration and treat some of the conclusions as hypotheses to be tested in representative studies.

A second reason for choosing this community was that the commune is familiar; it is one of the authors' main research sites for many of her recent sociological studies regarding social changes in the post-communist era (Șandru 2005, 2009). We used an ethnographic approach. We chose ethnography because ethnographic research represents a "firsthand study of society and culture in action" and ethnographers "now have to think about how to recognize and analyze change" (Murchison 2010). Ethnography provides a valid way to find out what is happening in a community or other social setting when the 
research problem has not yet been clearly identified or no data are available to understand a new social phenomenon (Silverman 2004; LeCompte, Schensul 2010).

In December 2011, three individual interviews (I1, I2, I3) and two family interviews (F1, F2), with both spouses, were conducted in Drăguş. We conducted family interviews in the cases where the whole family migrated. The participants in the research were three females and five males, aged between 27 and 45, with mid-level (secondary school or vocational school) education, who had graduated in Romania before leaving for Italy. Each of them spent between four and fifteen years in Italy. The data gathered included observations of the houses (interior and exterior), the gardens, the participants' clothing, speech, etc. We used the narrative technique for the interviews as it is generally used in biographic and narrative research (when subjects are asked to narrate a part of their life, their entire life or a historical episode that they have witnessed and so on). The conducting of the narrative interviews implies - before going out in the field - the preparation of a single question. This is called by some authors "generative" or "narrative" and has to somehow "generate" a story, to stimulate the participants to talk (see Flick 1998 or Boyatzis 1998). The narrative question that we asked was the following:

\footnotetext{
I'm very interested in the people in this village who lived abroad for a period of time and then returned. I would like you to tell me as much as you can about this experience. There are a lot of people that did not consider leaving the country or were unable to and that did not live far from their home. I would like you to explain to us how you coped with everything - emotions, feelings, experiences - good and bad. Please tell me in detail about your leaving, about the time spent away from your home and about the return home - about yourself in each of these life episodes. We are not in a hurry. I am interested in what was important to you, even though these things may seem small or insignificant.
}

The data were analyzed using coding procedures (see Strauss, Corbin 1990; Flick 1998) and NVivo software. Most of the resulting ethnographic reflections focus on the identity of our subjects. The results mostly describe the way the identity of our participants was shaped by the experience of migration and returning to the original community. We have tried to frame the results using different concepts and theories from identity literature, even if the theoretical approaches we refer to are different in scope, focus or historical times. It is an interpretation exercise aiming to underline the multitude and the diversity of identity processes that are associated with the migration experience. Thus an instrumental case study was conducted on the community of returned emigrants from Italy in Drăguş. The community itself is not a special case, but it is interesting in its resemblance to other cases (communities) in Romania. The case can be used as an instrument in understanding others that present similar migration traits.

\section{DATA INTERPRETATION}

The life of our subjects can be described as an experience of multiple identity conversions, as we will show below. 


\section{Being away from home}

\section{How do they think they were perceived by Italians?}

The participants believed they had not caused any problems in the country they lived in and even though they were praised by the natives there, they often felt that they were treated as unwanted intruders. Many of the respondents recount experiences with discrimination. Some of the participants were praised in the workplace: "you Romanian guys, I see you are hard-working and responsible" (I1). They were praised in school: "the teachers said: look, even though he is Romanian and not Italian, he learned the language and the lesson" (I2). They were able to integrate themselves with the locals by getting to know them, speaking with them and sometimes even visiting them in their homes. However, when a Romanian immigrant was accused of having committed a crime, they were treated quite differently: "they start quickly suspecting you of this and that just because you are Romanian; these things are not ok" (I1). Dubar (2003) claims that there are two ways to identify oneself: identifications attributed by others and identifications claimed by oneself. Identifications attributed by others are objective identities, such as assigning labels and statuses. (They can also be realistic or unrealistic.) It is easily noticeable in interviews how emigrants felt they were wrongly labeled, characterized or attributed with unwanted behaviors (based only on nationality or emigrant status - "being a 'migrant' is often a negative identity imposed by the dominant culture" (Benmayor, Skotnes 2005: 8).

The interviewees were embarrassed that the identifications claimed by themselves did not coincide with the identifications attributed by others during their stay abroad. It is possible that they could not change this discrepancy due to one major obstacle: their means of constructing and expressing their identity was restricted (the language is hard to master and poses a serious handicap; available jobs block their hierarchical advancement and they have no means of proving their competences). Peer identification is achieved by means of labeling. The Italians compared the interviewees with other Romanians rather than trying to distinguish them as individuals. They sort them into official groups, i.e. illegal immigrants, Romanians, unqualified workers, etc. instead of putting them into specific biographic trajectories (they did not seem interested in the Romanians' family members who were left in Romania, they did not seem to consider what could have forced our participants to decide to emigrate in the first place and also did not seem to take into account the fact that the interviewees would like to return home for the holidays to spend time with their loved ones). We believe that sometimes participants felt stigmatized due to the labeling they were subjected to.

The collective identity of Romanian emigrants in Italy seems to be generated by their social labeling (external collective definition) rather than by group identification (internal collective definition). In other words, Romanian emigrants' collective identity seems to be built (as the interviewees declared) less through Romanians' self-identifications and more through their external identifications that come from Italians. Romanians seem to resent this and try to avoid admitting their origins, as advertising their nationality only brings disadvantages. However, collective identification (by external assignment of common characteristics to a category of individuals - for example "Romanians are crooks") contributes to the shaping of individual identity. Romanians in Italy became "criminals" by associating this label with nationality, and some Italians' relations with Romanians are consistent with this label. By internalizing it, group categorization may become group identification, or as 
Jenkins (1996: 88) claims, "Groups come to identify as such due to initial categorization by others". This latter process does not seem to have happened, but the possibility is worth mentioning. Group identification always involves social categorization; conversely, social categorizations do not always involve group identification, they only create the possibility to become group identification. In Italy respondents do not identify with Romanians - in the generic pejorative label - but are often the subjects of this categorization.

Collective identity is "the ability of a community to recognize itself as a group" (Segrestin 1996: 127), and the main indicators of collective identity are living in a given territory, ethnicity, culture, religion, language, history and lifestyle (Kantner 2006). Although it would meet all the conditions to be recognized as a group, even though there are many Romanians in Italy and although such recognition would bring only benefits, a collective identity (in the sense of belonging) among those left does not form, and we claim that one reason is this categorization by generalizing negative attributes. Returning to our participants' narratives, employers trust them and they are given high-responsibility jobs: "they trusted him a lot, he was the boss in that yard: he locked it and he unlocked it ... he knew everything ..." (I2); "I think that if the boss trusts you it's only normal that he won't let you leave" (F2). Problems arise when Romanians ask for a Christmas vacation or when they ask for a late payment: "we understood that there was much work during that time, but Ionel kept saying that they have to understand us as well" (F2). Sometimes they feel like second-class people not because of the work they do, but because of the attitude of those they interact with: "as long as you work, you are praised, but if you have something to ask or say, things change" (I2).

Cooley's (cited in Chelcea 2006) theory claims that we are what we believe we are in the eyes of others, i.e. that the self is mirrored in others. We are reflected in others as in a mirror. It is likely that "mirrors" from abroad have reflected images in which Romanian emigrants do not recognize themselves. It is also possible that because of this, many felt estranged or different and unfitting. The aforementioned theory claims that when interacting with others, individuals interpret their gestures and create an image of themselves from the others' point of view. Thus, the sense of self and self-representation is the product of what others think about they and of what they think others think about them (about who and what they are). Or these participants' self-representation abroad was not one that would make Romanians proud of themselves (especially because most of the times the Italians' image of them was created based on preconceived ideas). The three components of the process of creating a looking-glass self-identity are the following (after Cooley, cited in Ritzer 1996): 1. we imagine how we appear to others; 2 . we imagine what their judgment of this issue is; 3 . we develop feelings such as pride or shame as a result of imagining others' judgments. Even though it is not true, the majority of the interviewees imagined that Italians considered them second-class citizens, and consequently it is highly probable that many of them developed feelings of shame during their stay in Italy.

It is possible that self-esteem, with its component of social self-esteem (see Heatherton, Vohs 2000) is the most affected characteristic among Romanian emigrants. Social self-esteem refers to the way in which people think they are perceived by others. It is possible that living abroad caused discrepancies between self-conception (what someone thinks is true about them - Italians seem to have shattered these "truths" about themselves) and their ideal selves (desired or hoped). The bigger these discrepancies are, the lower the self-esteem (see Crocker, Bylsma 1996). According to the Gale Encyclopedia of Psychology (Strickland 
2001) there are three categories of the self: the personal (someone's facts or opinions about her or himself), the social (someone's perceptions of how she or he is seen by others) and the ideal (what or how one would like to be). The discrepancies between these categories present in our interviewees create identity imbalances.

\section{How do they perceive Italians?}

Our participants believe that Italians need Romanians' help. There are jobs that they will not do and for which they would pay too much by hiring locals; thus they resort to Romanians: "this family really needed a house-keeper" (I2). The majority of those people the interviewees interact with are people that help them in return: "they were really attached" (F1); "she became friends with her neighbor [...] she was a retired granny who had nobody, so they visited each other" (I1). But there are also locals that disappoint them greatly. Our participants consider many of them as being opportunistic, well-intended and understanding until the point where they need you, but clear-cut and malevolent when they do not need you: "we took our flowers with their pots, the flowers we grew; we put them in the car - and the granny said that she will call the police, the 'carabinieri', that we stole the flowers and so on; this is how they were ... everything is good when they need you" (I1).

There are a few identity concepts that can be found in our interviews: for example, peer identification (Iluț 2001), with their variants of how they think Italians identify them and how they identify Italians. Generally, these two identifications are not flattering and even though there is not enough information to support this, it appears quite clear that there are essential discrepancies between how participants think they are identified by Italians and how they perceive themselves and between how they identify Italians and how Italians perceive themselves. The two processes of identification are hetero-identification (how they are identified from the outside) and self-identification (what individuals think about them, with whom and with what they identify) (see Iluţ 2001). Quite often we can notice significant differences between the categories one identifies with and those with which others identify the same person. Iluţ claims that individuals dislike noticing this difference and, through multiple and varied feedback there are continuous adjustments between the two. Nevertheless, given the (qualitatively) quite limited contact between Romanians and Italians, these adjustments are also limited.

\section{Being at home again ${ }^{1}$}

Identity problems do not end with the decision to return to Romania. Our respondents often talked about the frustrations they have when re-adapting to life in their country of origin. They thought that returning home would be a relief, but this stage is also difficult. Our findings are consistent with others: "the returnees are alienated from their compatriots and no longer feel at home in their home countries" (Sussman 2010: 7), and with the concept of "double absence" (Sayad 2004), meaning that emigrants/immigrants are considered, to a certain degree, foreigners in their country of origin, as well as in the country of emigration, where they did "not really have a place" (Noiriel 2007).

1 Some of the findings in this subsection are also listed in Șandru, Scârneci 2014: 64-75. 


\section{How do they think emigration changed them?}

There are obvious things when looking at our participants that remind one of the fact that they emigrated (for example, house designs, clothing or foreign accents when speaking): all of the participants have a slight Italian accent in pronunciation, in the way they pronounce and extend certain vowels. One of our participants even uses Italian words in sentences: bollette ('invoices'), spesa ('shopping') etc. Some of these changes are conscious: one of the participants declared that on his return he avoided speaking with an Italian accent so that people did not consider him posh. The conscious changes also include elements of gastronomy, interior design and one's own upbringing:

Do you eat Italian now? Do you cook? Pasta, I ask her quite often to cook pasta. And if we go out, as we do sometimes, I prefer pasta. [...] Of course, you realize that by living there you probably copied their clothes or clothing style, or the food and we borrowed many things, at least the pasta ... (I1)

Even though they live in rural areas, their houses' interior designs are modern and urban: since returning home, one participant has invested in building a bath and installing wooden floors in all the three rooms (plus the kitchen). Another participant's house is modernized, with modern designs and furniture, with modern decorative elements (for example curtains). One female interviewee's house stands out through its conspicuously western design. Instead of a traditional wooden gate, there is an Italian-style wrought-iron gate through which one can see the inside yard, which is beautifully designed with round flower beds, traditional wooden decorative elements, a terrace and paths. She says that many of the villagers consider the gate a curiosity and often ask if they are not annoyed by "people looking inside the yard". The house's interior is quite modern: sandstone floors - typically Italian - in the living room and the kitchen, a guest room and the family's upstairs bedrooms. Their parents' house is in the same yard, but separate, and our respondent states that this is where her mother cooks for everybody and where they all eat, because her kitchen with all the modern appliances is "only a coffee place". The house is painted in bright colors, with recessed lights in the ceiling, and there are two LED TVs (one in the kitchen and one in the living room).

It is possible that those who saved up money abroad are proud of their success and might show off the influence of another culture. We can see that this influence is not noticeable among those who claimed to have had a rough time abroad and did not save very much. Clothing is an example: the "richer" are the most modern and opulent in their clothing: he - designer clothes, a big gold chain around his neck and designer shoes; she - modern clothes: black jeans and a red cardigan. Others wear sports attire; one of them wore a traditional woolen Romanian sweater and seemingly cheap boots. Food is another element: some cook pasta very often, while others that worked in Italy as pizza cooks for example say they have never cooked Italian since their return, because they are "sick" of it. Some of the most important changes brought by working abroad were the improvement of their material status and learning new job skills: "I can say that Italy changed us from this and only this point of view, that we made money; it helped us financially so we could build this house and so on" (I2); "I learned a new trade, which is good; this is my greatest achievement ..." (I3); "It was my biggest achievement, because one cannot starve with such a trade ..." (I3). 


\section{What do those at home say about emigrants?}

Those who managed to improve their way of life after their return are both admired and envied by others. And those who returned also consider themselves unjustly envied, claiming that they have made great sacrifices for the money they earned. Self-discrepancies (after Chelcea 2006) are mismatches between the different states of the self: between the actual self - self-representation, ideal self - what the person him or herself desires, and the desired self as expected by significant others. It is possible that there are discrepancies between these states of the self among Romanians who emigrated and returned home. The sometimes humiliating experiences they experienced abroad create discrepancies between what they think of themselves (in those circumstances) and what they want for themselves (and think they are entitled to). When they return home, they try to make up the realities of their life abroad so that they meet the expectations of their friends and relatives. What Romanian emigrants experience can be categorized as what Goffman (1961) called "biographical ruptures" which activate and reactivate the inconsistencies between the "real social identity" (own characteristics) and the "virtual social identity" (as they appear to others in interaction). Inconsistencies are developed within interactions with others, both Italians during their time in Italy and Romanians upon their return.

\section{What do the subjects say about other Romanian emigrants?}

The interviewees talk about success stories and failures related to leaving for work abroad. There are Romanians who, according to them, worked abroad and did not save any money, and there are Romanians who saved a lot. Some confess that there is a certain competition between emigrants. They watch each other and observe the way in which they succeeded: "There were some who worked in Italy and came back with nothing. Now, I cannot say otherwise about us, or what we did ... because there are others who came back with even more than us ..." (I2); "There was a competition ... one earns more, one earns less, one wants a car, another wants two ..." (F1).

Entering such a contest, some emigrants spent their money on status symbols, while others took advantage of the relationships they built with other Romanians abroad and on their return home they started various businesses together: "We'll get more work, let's cooperate! [...] For example, we worked in Poiana Braşov, at Copos at his hotel and we had to merge four companies ... that is, four men who had companies ... and we had all worked abroad" (F2). Vlase (2011) shows that those who return from Italy contribute to the construction of a local imaginary by detailing their experiences and displaying various brands of this society (clothes, cars and other products brought from Italy). In our opinion these visible elements contributed greatly to the establishment of the motivation to go work in Italy, especially in the 1990s. They are status markers which cause their owners to be considered successful, and Italy a country where financial success come fast in just a few years of work.

\section{CONCLUSION}

We want through this article to draw attention to return migration, the most neglected migration process in the specialty literature. It does exist and it produces economic, social and cultural effects at the level of the communities of origin. Secondly, we wanted to prove 
the richness and the immense suggestive power of qualitative data in regard to the experience of migration. The statistic and demographic data cannot describe the phenomenon in the complexity of its characteristic transformations. And thirdly, we wanted to underline the importance of focusing on the individual and collective identity phenomena that accompany migration.

The experience of migration that has been described here illustrates the post-modern view of identity. It considers that the individual has no permanent or fixed identity, but assumes different identities in different moments. This characteristic raises many identity issues: identity disruptions and fragmentations, identity crises, decentering (the existence of more identities, some of them being contradictory), with serious personal and social effects. The literature mentions identity dysfunctions. Dubar (2003) calls identity crises the disruptions which appear in self-identification and other identification. One of the main factors which generate such identity crises is sudden significant life changes, for example divorce, retirement etc. - "they disrupt the image and self-respect, the very definition one gives to oneself" (p. 159). Migration is undoubtedly such a factor, as it implies the change of bearings, models, beliefs, values and even the change of the individual itself.

One of the solutions to overcoming an identity crisis, claims the above mentioned author, is identity conversion. This necessitates the shift from one identity to another: we become someone else, we change our culture, religion etc.; it implies abandoning the old identity (protective, resulting from the original social life) and the construction of a new identity (developed from secondary social experiences). Participants' identity crises and conversions appear both upon leaving the country and upon their return. Migration generates more or less permanent identity maladjustments: in Italy they were never fully adapted (neither when they had legal papers, nor when they had learned the language or when they became indispensable to Italians): they were not Italian, but not fully Romanian either; in Romania they are not and they will never be again what they once where (they have changed and they are perceived as being different).

Even though the discourse of our interviewees is not gloomy, in general the interviews leave the impression of a quite harsh migration experience. The hardships are pretty severe, diverse and always present during this experience, and there are aspects specific to migration that have caused important problems in their identity equilibrium. In this context, the words of one interviewee would be justified: "If I had to leave, or if I had to choose, I would not leave again" (I1). Even if some of the participants were very proud of their achievements abroad and at home after their return, we can conclude that none of them would repeat the migration experience. Therefore, the experience of migration sets one back at an identity level. Our participants (and most of the times their relatives at home) experienced significant changes in identity. Some have improved their material status, others assured their future, others grew up, others sealed their family relationships, others showed Italians what Romanians are like, and others brought a bit of style to the community of Drăguş, etc. But all of them acquired experiences that made them different from the rest of Romanians. And given the increasing numbers of those who left and returned, we think that - from a sociological point of view - more attention should be given to this category of Romanians as well as to the transformations of the communities to which they return. 


\section{REFERENCES}

Adamson, Kay (2007). Emigration-immigration: Abdelmalek Sayad 's Sociology of Migration. North African Mosaic: A Cultural Reappraisal of Ethnic and Religious Minorities (eds. Nabil Boudraa, Joseph Krause). Newcastle: Cambridge Scholars Publishing, 119-134.

Anghel, Remus Gabriel (2009). Schimbare socială sau dezvoltare? Studiu de caz într-un oraş din România. Sociologia migraţiei. Teorii şi studii de caz româneşti (coord. Istvan Horvath, Remus Gabriel Anghel). Iaşi: Polirom, 249-267.

Bălţătescu, Sergiu (2007). Central and Eastern Europeans Migrants' Subjective Quality of Life: A Comparative Study. Journal of Identity and Migration Studies 2, 67-81.

Benmayor, Rina, Skotnes, Andor (2005). Some Reflections on Migration and Identity. Migration and Identity (eds. Rina Benmayor, Andor Skotnes). New Jersey: Transaction Publishers, 1-18.

Boyatzis, Richard (1998). Transforming Qualitative Information: Thematic Analysis and Code Development. Thousand Oaks: Sage Publications.

Brubaker, Rogers (2009). Migraţiile dezeterogenizării etnice în “Noua Europă”. Sociologia migraţiei: Teorii şi studii de caz româneşti (coord. Istvan Horvath, Remus Gabriel Anghel). Iaşi: Polirom, 65-85.

Chaban, Natalia, Williams, Allan, Holland, Martin, Boyce, Valerie, Warner, Frendehl (2011). Crossing Cultures: Analysing the Experiences of NZ Returnees from the EU (UK vs. non-UK). International Journal of Intercultural Relations 35, 776-790.

Chelcea, Septimiu (coord.) (2006). Psihosociologie: Teorie şi aplicaţii. Bucharest: Editura Economică.

Chiang, Lan-hung Nora, Liao, Pei-Chun Sunny (2008). Back to Taiwan: Adaptation and Self-Identity of Young Taiwanese Return Migrants from Australia. Journal of Population Studies 36, 99-135.

Cingolani, Pietro (2010). Prin forte proprii: Vieti transnationale ale migrantilor romani in Italia. Sociologia migraţiei: Teorii şi studii de caz româneşti (coord. Istvan Horvath, Remus Gabriel Anghel). Iaşi: Polirom, 176-194.

Crocker, Jennifer, Bylsma, Wayne (1996). Self-esteem. The Blackwell Encyclopedia of Social Psychology (eds. Anthony Manstead, Miles Hewstone), http://www.blackwellreference.com/ subscriber/tocnode?id=g9780631202899_chunk_g978063120289921_ss1-10 (6. 4. 2017).

Dăianu, Daniel, Voinea, Liviu, Tolici, Mugur (2001). Balance of Payments Financing in Romania: The Role of Remittances. Bucharest: Romanian Centre for Economic Policies, http://pdc.ceu.hu/archive/00002165/_(21. 2. 2012).

Dubar, Claude (2003). Criza identităţilor: Interpretarea unei mutaţii. Chişinău: Editura Ştiinţa. Flick, Uwe (1998). An Introduction to Qualitative Research. London: Sage Publications. Goffman, Erving (1961). Stigma. EngleWood Cliffs: Pretince Hall.

Heatherton, Todd, Vohs, Kathleen (2000). Self-Esteem. Encyclopedia of Sociology (eds. Edgar Borgatta, Rhonda Montgomery). New York: Macmillan Reference.

Horvath, Istvan (2009). Aspecte ale culturii migraţiei în România. Sociologia migraţiei. Teorii şi studii de caz româneşti (coord. Istvan Horvath, Remus Gabriel Anghel). Iaşi: Polirom, 156-175.

Iluţ, Petru (2001). Sinele şi cunoaşterea lui: Teme actuale de psihosociologie. Iaşi: Polirom. Jenkins, Richard (1996). Social Identity. London: Routledge.

Jones, Richard (2011). The Local Economic Imprint of Return Migrants in Bolivia. Population, Space and Place 17, 435-453. 
Kantner, Cathleen (2006). Collective Identity as Shared Ethical Self-Understanding: The Case of the Emerging European Identity. European Journal of Social Theory 9/4, 501-523.

Kunuroglu, Filiz, Yagmur, Kutlay, Van de Vijver, Fons J. R., Kroon, Sjack (2015). Consequences of Turkish migration from Western Europe. International Journal of Intercultural Relations 49, 198-211.

LeCompte, Margaret D., Schensul, Jean J. (2010). Designing and Conducting Ethnographic Research: An introduction. Lanham: Alta Mira Press.

Michalon, Benedicte (2009). Cât de specifice sunt migraţiile germanilor din România? Etnicitate, reţele şi circulaţie migratorie. Sociologia migraţiei: Teorii şi studii de caz româneşti (coord. Istvan Horvath, Remus Gabriel Anghel). Iaşi: Polirom, 86-104.

Murchison, Julian M. (2010). Ethnography Essentials: Designing, Conducting, and Presenting Your Research. San Francisco: Jossey-Bass.

Noiriel, Gérard (2006). Colonialism, Immigration, and Power Relations. Qualitative Sociology 29/1, 105-110.

Parati, Graziella (2005). Migration Italy: The Art of Talking Back in a Destination Culture. Toronto: University of Toronto Press.

Ritzer, George (1996). Sociological Theory. McGraw Hill Inc.

Sayad, Abdelmalek (2004). The Suffering of the Immigrant. Cambridge UK, Malden Mass: Polity Press.

Sandu, Dumitru (2010). Lumile sociale ale migraţiei româneşti în străinătate. Iaşi: Polirom.

Segrestin, Denis (1996). Identitate colectivă. Larousse dicţionar de sociologie (coord. Raymond Boudon, Philippe Besnard, Mohamed Cherkaoui, Bernard Pierre Lecuyer). Bucharest: Univers Enciclopedic.

Silverman, David (2004). Interpretarea datelor calitative. Iasi: Polirom.

Stake, Robert (1998). Case Studies. Strategies of Qualitative Inquiry (eds. Norman Denzin, Yvonna Lincoln). London: Sage Publications.

Strauss, Anselm, Corbin, Juliet (1990). Basics of Qualitative Research: Grounded Theory Procedures and Techniques. London: Sage Publications.

Strickland, Bonnie (ed.) (2001). The Gale Encyclopedia of Psychology. Michigan: Gale Group.

Sussman, Nan (2010). Return Migration and Identity: A Global Phenomenon, a Hong Kong Case. Hong Kong: Hong Kong University Press.

Şandru, Codrina (2005). Formarea noii elite economice a satului Drăguş în perioada post-comunistă. Catalyse. Cunoaştere, participare şi dezvoltare în spaţiu comunitar (coord. Mihai Pascaru). Cluj-Napoca: Argonaut, 147-169.

Şandru, Codrina (2009). Studii şi confesiuni despre Drăguşul contemporan. Cluj-Napoca: Presa Universitară Clujeană.

Şandru, Codrina, Scârneci, Florentina (2014). Italia-Romania - l'esperienza completa della migrazione. Calimera, Italy: Kurumuny.

Thieme, Susan (2012). Coming Home? Patterns and Characteristics of Return Migration in Kyrgyzstan. International Migration, http://onlinelibrary.wiley.com.ux4ll8xu6v.useaccesscontrol.com/doi/10.1111/j.1468-2435.2011.00724.x/abstract (23. 2. 2012).

Toanchină, Camelia (2006). Migraţia internaţională şi politicile sociale. Iaşi: Lumen.

Vlase, Ionela (2011). Migraţia de întoarcere a românilor din Italia: Studiu de caz în Vulturi, Vrancea. Revista Calitatea Vieţii 2, http://www.revistacalitateavietii.ro/2011/CV-22011/03.pdf (21. 2. 2012). 


\section{POVZETEK}

\section{ETNOGRAFSKI ODSEVI POVRATNE MIGRACIJE V RURALNI ROMUNSKI SKUPNOSTI Florentina SCÂRNECI DOMNIȘORU, Codrina CSESZNEK}

Avtorici sta v etnografski študiji romunske ruralne skupnosti z dolgo zgodovino emigracij s poudarkom na procesu spreminjanja identitete demografske in kvantitativne podatke dopolnjevali s pričevanji in z izkušnjami ljudi. Raziskovali sta v migrantski skupnosti v Drăguşu, katere člani so se vrnili iz Italije. Skupnost omogoča primerjavo z drugimi (ruralnimi skupnostmi) v Romuniji in razumevanje drugih značilnosti migracij. S pričujočim člankom sta želeli: 1) poudariti, da so povratne migracije v strokovni literaturi najbolj zanemarjen del migracijskega procesa, čeprav imajo v izvornih skupnostih ekonomske, socialne in kulturne učinke; 2) dokazati vrednost in izjemno sugestivno moč kvalitativnih podatkov o migraciji, saj statistični in demografski podatki ne morejo zajeti večplastnost pojava; 3) poudariti pomen ukvarjanja tako $\mathrm{z}$ individualnimi kot s skupinskimi spremembami identitet. Migracije ljudem povzročajo identitetne težave: tisti, ki sta jih raziskovali, se v Italiji nikoli niso polno integrirali (niti v primeru urejenih dokumentov, znanja jezika ali nepogrešljivosti za domačine); v Italiji niso bili niti Italijani niti Romuni, v Romuniji pa nikoli več ne bodo, kar so bili pred odhodom (ker so se spremenili, nanje ljudje gledajo drugače): niso niti Italijani niti pravi Romuni. Vsi so se na nek način spremenili: nekateri so izboljšali svoj materialni status in si zagotovili boljšo prihodnost, drugi so odrasli in si uredili družinske razmere, nekateri pa so v Drăguş prinesli italijanska stil in modo. Izkušnja vseh je bila, da so se Italijanom predstavljali kot boljši od drugih Romunov. Glede na število tistih, ki so odšli in se vrnili, sta avtorici prepričani, da je treba - s sociološkega stališča - posvetiti več pozornosti tako tej kategoriji Romunov kot transformaciji skupnosti, v katere so se vrnili. 